\title{
The Effect of Implementation of Report Online Application on User Satisfaction and Operational Performance
}

\author{
Slamet Widodo Magister Management Program \\ Mercu Buana University \\ Jakarta, Indonesia
}

\begin{abstract}
This study aims to determine and analyze the effect of applying the Report Online Application to User Satisfaction and Operational Performance. The object of research is the employee of the Directorate General of SDPPI by using purpose sampling techniques and the number of samples 143 respondents. This research is a causal associative type through a questionnaire that is measured with a differential semantic scale with the lowest point 1 to the highest point 10 and analyzed with Structural Equation Modeling (SEM) AMOS 23. The results show that the application of Report Online applications has a positive effect on user satisfaction, user satisfaction has a positive effect on operational performance and the implementation of Report Online application has a positive effect on operational performance
\end{abstract}

Keywords:- Reporting, User Satisfaction, Operational Performance, Amo).

\section{INTRODUCTION}

Changes in the global environment and the rapid development of telecommunications technology have led to fundamental changes, result to a new telecommunications environment, and changes in perspective in the operation of telecommunications, including the results of convergence with information and broadcasting technology, thus it is deemed necessary to reorganize national telecommunications operations (Telecommunications Law Number 36, 1999). Radio frequency spectrum and satellite orbit are limited natural resources, and the use of radio frequency spectrum must be in accordance with its purpose and not interfere with each other (Government Regulation Number 53, 2000).

The Ministry of Communication and Information through the Directorate General of Resources and Equipment of Post and Information Technology (DG SDPPI) is a regulator of the radio frequency spectrum field equipped with an integrated Radio Frequency Monitoring System consisting of hardware and software for to observe and monitor, identify and handle radio frequency disturbances. The use of information technology in government policy is currently very massive, however the effectiveness and test of the influence of factors influencing the effectiveness of the application of an application itself is still rarely done. Thus, there is still little empirical data based on the results of research that can be used as a

\author{
Niken Sulistyowati Magister Management Program \\ Mercu Buana University \\ Jakarta, Indonesia
}

guideline to measure the successful use of application systems to improve operational performance. Previous research explains that technology skills affect work productivity (Agus Tri Indah K, 2017), the use of information systems can affect work productivity (Ardianto Ridho Putra Tri Indra Wijaksana, S. Sos., M.Sc, 2015), performance and management capabilities information has a positive effect on organizational performance (Kuo-En Huang Jih-Hwa Wu, Shiau-Yun Lu, Yi-ChiaLin, 2014), there is a strong influence between the effectiveness of regional information systems and employee performance (Dona Primasari, 2013).

This study will look at the extent of the influence of the use of Report Online applications that are used as tools for operational reporting monitoring on improving operational performance. This study will also examine how much influence the satisfaction felt by application users on improving operational performance. It is hoped that this research will find out what factors in the application affect operational performance and affect user satisfaction.

\section{THEORITICAL REVIEW}

\section{A. Management Information System}

Management information systems are the study of computers and computing in a business environment. Computer science focuses on machines while information systems, or management information systems, focus on how information technology can support an organization's strategy and operations (Maeve Cummings, 2002). The use of information and communication technology in government is a transformation in the way services are provided by the government using technology, especially web-based ones (Cropf, 2017).

\section{B. Technology Acceptance Model (TAM) \\ Technology Acceptance Model (TAM) is a model used to measure the acceptance of information systems by looking at perceived usefulness, perceived ease of use, attitude of desire to use (behavior intention to use) and actual system usage conditions (Davis, FD., 1989). TAM also explains and predicts how the user's acceptance of the technology as well as explains the behavior of its use (Jogiyanto, HM., 2007).}


ISSN No:-2456-2165

\section{User Satisfcation}

User satisfaction is a feeling of pleasure or disappointment caused by comparing the performance / results with the desired expectations (Kotler and Keller, 2009). The satisfaction and use of information technology can be measured by several models, one of which is by using DeLone and McLean's theory (D\&M IS Success Model). In the D\&M success model, information quality, System Quality and Service Quality are factors that determine the level of user satisfaction.

\section{Operational Performance}

Performance is a description of the level of achievement of the implementation of a program of activities or policies in realizing the goals, objectives, and mission of the organization (Moeheriono, 2009). Operational performance is related to the use of each resource used by the organization, that is, how much is the maximum use to achieve profits or achieve the vision and mission. To measure operational performance according to (Terziovski and Samson 1997, sit. Herlambang 2009), it can be measured by the level of productivity, the level of production errors, adequate technology and the accuracy of the product to consumers. Performance is a description of the level of achievement of the implementation of a program of activities or policies in realizing the goals, objectives, and mission of the organization (Moeheriono, 2009). Operational performance is related to the use of each resource used by the organization, that is, how much is the maximum use to achieve profits or achieve vision and mission.

\section{E. Thinking Framework and Hypothesis}

The authors formulated the thinking framework based on theory as follows:

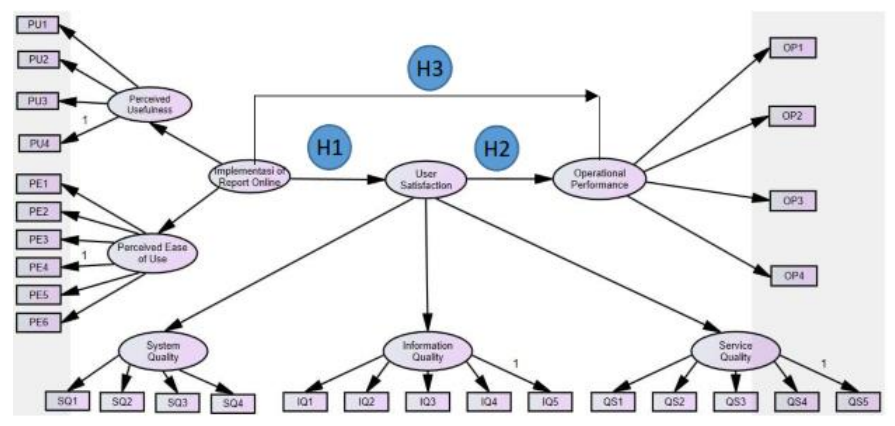

Fig 1:- Research Framework

Figure 1 shows the research variables consisting of 3 (three) variables, namely the Implementation of Report Online Application, User Satisfaction \& Operational Performance. Implementation of Report Online Application Variables are measured from indicators which are divided into 2 (two) dimensions, namely Perceived Usefulness (PU1, PU2, PU3, PU4, PU5) and Perceived Ease of Use (Perceived Ease of Use) (PE1, PE2, PE3, PE4, PE5). Variable of User Satisfaction are measured from indicators that are divided into 3 (three) dimensions namely Information Quality (IQ1, IQ2, IQ3, IQ4), System Quality (SQ1, SQ2, SQ3, SQ4, SQ5), Service Quality (QS1, QS2, QS3, QS4, QS5)

\begin{tabular}{|c|c|c|c|}
\hline Variable & Dimension & Indicator & Code \\
\hline \multirow{10}{*}{$\begin{array}{l}\text { Implementation } \\
\text { of the Report } \\
\text { Online } \\
\text { Application }\end{array}$} & \multirow{4}{*}{$\begin{array}{l}\text { Perceived } \\
\text { Usefulness }\end{array}$} & $\begin{array}{l}\text { Application } \\
\text { Productivity }\end{array}$ & PU1 \\
\hline & & $\begin{array}{c}\text { Task performance } \\
\text { (application } \\
\text { effectiveness) } \\
\end{array}$ & PU2 \\
\hline & & $\begin{array}{l}\text { The level of } \\
\text { importance of the } \\
\text { application to carry } \\
\text { out the task } \\
\text { (importance to job) }\end{array}$ & PU3 \\
\hline & & $\begin{array}{c}\text { Overall application } \\
\text { usefulness }\end{array}$ & PU4 \\
\hline & \multirow{6}{*}{$\begin{array}{l}\text { Ease } \\
\text { (Perceived } \\
\text { ease of } \\
\text { use) }\end{array}$} & easy to learn & PE1 \\
\hline & & Controllable & PE2 \\
\hline & & $\begin{array}{c}\text { The application is } \\
\text { clear and easy to } \\
\text { understand }\end{array}$ & PE3 \\
\hline & & Flexibility & PE4 \\
\hline & & $\begin{array}{c}\text { Free from } \\
\text { difficulties (easy } \\
\text { become skilful) }\end{array}$ & PE5 \\
\hline & & Ease of use & PE6 \\
\hline
\end{tabular}

Table 1:- Operational Variables for Application of Report Online

\begin{tabular}{|c|c|c|c|}
\hline Variable & Dimension & Indicator & Code \\
\hline \multirow{14}{*}{$\begin{array}{c}\text { User } \\
\text { Satisfaction }\end{array}$} & \multirow{4}{*}{$\begin{array}{l}\text { System } \\
\text { Quality }\end{array}$} & Convenient Use & SQ1 \\
\hline & & System Flexibility & SQ2 \\
\hline & & System Integrity & SQ3 \\
\hline & & Response Time & SQ4 \\
\hline & \multirow{5}{*}{$\begin{array}{c}\text { Quality } \\
\text { Information }\end{array}$} & Accuracy & IQ1 \\
\hline & & Relevance & IQ2 \\
\hline & & $\begin{array}{l}\text { Completeness of } \\
\text { Information }\end{array}$ & IQ3 \\
\hline & & Timeliness & IQ4 \\
\hline & & Format Information & IQ5 \\
\hline & \multirow{5}{*}{$\begin{array}{l}\text { Service } \\
\text { Quality }\end{array}$} & Tangible & QS1 \\
\hline & & Reliability & QS2 \\
\hline & & $\begin{array}{c}\text { Freshness } \\
\text { (Responsiveness) }\end{array}$ & QS3 \\
\hline & & Assurance & QS4 \\
\hline & & Empathy & QS5 \\
\hline
\end{tabular}

Table 2:- Operational Variables of User Satisfaction

\begin{tabular}{|c|c|c|}
\hline Variable & Indicator & Code \\
\hline \multirow{3}{*}{$\begin{array}{c}\text { Operational } \\
\text { Performance }\end{array}$} & Reporting output generated & OP1 \\
\cline { 2 - 3 } & Reporting Speed & OP2 \\
\cline { 2 - 3 } & Reporting Accuracy & OP3 \\
\cline { 2 - 3 } & Reporting error rate & OP4 \\
\hline
\end{tabular}

Table 3:- Operational Variables of Operational Performance 
Based on the above framework, a research hypothesis is set as follows:

H1: Implementation of the Report Online Application has a positive effect on User Satisfaction

$\mathrm{H} 2$ : User Satisfaction has a positive effect on Operational Performance

H3: Implementation of the Report Online application has a positive effect on Operational Performance

\section{METODOLOGY}

Researchers used primary data by compiling indicators in the form of questionnaires and distributing them to samples using internet media. Respondents' answers in the form of opinion responses are measured using an interval scale of $0-10$ where 0 is the lowest answer score and 10 is the highest answer score (Ferdinand, 2014). The sampling method in this study was conducted using the Purposive
Sampling method using Structural Equation Modeling (SEM) data analysis tools using the AMOS 23 application. The sample population was taken from the Directorate General of SDPPI employees who used Report Online application. Stages of testing conducted in this study include Confirmatory Analysis Factor (CFA) Test, Average Variance Extracted, Construct Reliability, Normality Test, Goodness of Fit and Hypothesis Test.

\section{RESEARCH RESULT}

\section{A. Characteristics of respondents}

Respondents in this research are 143 respondents from the Directorate General of SDPPI consisting of the head office and UPT Radio Frequency Monitoring Center who used the Report Online application spread throughout Indonesia. Characteristics of respondents can be seen as follows:

\begin{tabular}{|c|c|c|}
\hline Characteristics of Respondents & Frequency & Percentage \\
\hline \multicolumn{3}{|l|}{ Gender } \\
\hline Male & 106 & $74.1 \%$ \\
\hline Girl & 37 & $25.9 \%$ \\
\hline \multicolumn{3}{|l|}{ Age } \\
\hline 20 to $<25$ years & 11 & $7.7 \%$ \\
\hline 25 to $<30$ years & 12 & $8.4 \%$ \\
\hline 30 to $<35$ years & 19 & $13.3 \%$ \\
\hline$\geq 35$ Years & 101 & $70.6 \%$ \\
\hline \multicolumn{3}{|l|}{ Head Office Work Unit } \\
\hline Directorate of Control & 29 & $74.4 \%$ \\
\hline Directorate of Operations & 6 & $15.4 \%$ \\
\hline Secretary of Director General & 5 & $12.8 \%$ \\
\hline \multicolumn{3}{|l|}{ UPT Work Unit } \\
\hline UPT Aceh & 1 & $0.7 \%$ \\
\hline UPT Ambon & 2 & $1.4 \%$ \\
\hline UPT Bandung & 6 & $4.3 \%$ \\
\hline UPT Banjarmasin & 4 & $2.8 \%$ \\
\hline UPT Batam & 4 & $2.8 \%$ \\
\hline UPT Bengkulu & 3 & $2.1 \%$ \\
\hline UPT Denpasar & 3 & $2.1 \%$ \\
\hline UPT Gorontalo & 2 & $1.4 \%$ \\
\hline UPT Jakarta & 4 & $2.8 \%$ \\
\hline UPT Jambi & 6 & $4.3 \%$ \\
\hline Jayapura UPT & 1 & $0.7 \%$ \\
\hline UPT Kendari & 3 & $2.1 \%$ \\
\hline Kupang UPT & 4 & $2.8 \%$ \\
\hline UPT Lampung & 9 & $6.4 \%$ \\
\hline Makassar UPT & 6 & $4.3 \%$ \\
\hline Mamuju UPT & 4 & $2.8 \%$ \\
\hline UPT Manado & 4 & $2.8 \%$ \\
\hline UPT Mataram & 4 & $2.8 \%$ \\
\hline UPT Medan & 8 & $5.7 \%$ \\
\hline Merauke UPT & 2 & $1.4 \%$ \\
\hline UPT Padang & 2 & $1.4 \%$ \\
\hline Palangkaraya UPT & 7 & $5.0 \%$ \\
\hline UPT Palembang & 6 & $4.3 \%$ \\
\hline UPT Palu & 5 & $3.5 \%$ \\
\hline UPT Pangkal Pinang & 4 & $2.8 \%$ \\
\hline UPT Pekanbaru & 8 & $5.7 \%$ \\
\hline UPT Pontianak & 4 & $2.8 \%$ \\
\hline
\end{tabular}


ISSN No:-2456-2165

\begin{tabular}{|c|c|c|}
\hline UPT Samarinda & 5 & $3.5 \%$ \\
\hline UPT Semarang & 3 & $2.1 \%$ \\
\hline UPT Surabaya & 2 & $1.4 \%$ \\
\hline UPT Tangerang & 5 & $3.5 \%$ \\
\hline Tanjung Selor UPT & 4 & $2.8 \%$ \\
\hline Ternate UPT & 3 & $2.1 \%$ \\
\hline UPT Yogjakarta & 3 & $2.1 \%$ \\
\hline \multicolumn{3}{|l|}{ Section / Work Position } \\
\hline Etc & 1 & $0.7 \%$ \\
\hline Monitoring and Ordering & 95 & $66.9 \%$ \\
\hline Monitoring and Control, Others & 1 & $0.7 \%$ \\
\hline Monitoring and Ordering, Facilities and Services, Administration & 1 & $0.7 \%$ \\
\hline Monitoring and Ordering, Administration & 1 & $0.7 \%$ \\
\hline Facilities and Services & 34 & $23.9 \%$ \\
\hline Administration & 9 & $6.3 \%$ \\
\hline \multicolumn{3}{|l|}{ Years of service } \\
\hline$<5$ years & 27 & $18.9 \%$ \\
\hline$>15$ years & 42 & $29.4 \%$ \\
\hline $10-<15$ years & 69 & $48.3 \%$ \\
\hline $5-<10$ years & 5 & $3.5 \%$ \\
\hline
\end{tabular}

Table 4:- Characteristics of Respondents

B. Validity and Reliability Test

$>$ Variable of Implementation of Report Online Application

\begin{tabular}{|c|c|c|c|c|}
\hline & & & $\mathrm{P}$ & Estimate \\
\hline Perceived Usefulness & $<--$ & Implementation of Report Online & & 1.000 \\
\hline Perceived of Use & $<--$ & Implementation of Report Online & & 1.000 \\
\hline PU4 & $<-$ & Perceived Usefulness & & 1.000 \\
\hline PU3 & $<--$ & Perceived Usefulness & $* * *$ & 1.072 \\
\hline PU2 & $<--$ & Perceived Usefulness & $* * *$ & 1.194 \\
\hline PU1 & $<--$ & Perceived Usefulness & $* * *$ & 1.166 \\
\hline PE6 & $<-$ & Perceived of Use & & 1.000 \\
\hline PE5 & $<-$ & Perceived of Use & $* * *$ & 1.086 \\
\hline PE4 & $<-$ & Perceived of Use & $* * *$ & .999 \\
\hline PE3 & $<-$ & Perceived of Use & $* * *$ & 1.006 \\
\hline PE2 & $<--$ & Perceived of Use & $* * *$ & .980 \\
\hline PE1 & $<-$ & Perceived of Use & $* * *$ & .955 \\
\hline
\end{tabular}

Table 5:- Regression Weights and Standardized Weights of Implementation of Report Online Application Variable

CFA Test Results for all indicators of dimensions and variables have a probability of 0.001 (***) with loading estimates > 0.05 so that all indicators and dimensions are valid and represent the variables (Ghozali, 2017). The loading value of standardized estimate indicators for the application of PU1 Report Online (0.865), PU2 (0.906), PU3 (0.643), PU4 (0.842) to the dimensions of Perceived of Usefulness and indicators for PE1 (0.864), PE2 (0.874), PE3 (0.842) 0.923), PE4 (0.831), PE5 (0.868), PE6 (0.903) to the Perceived of Use dimension. The Dimension of Perceived Usefulness is (0.934), the Dimension of Ease is (0.869) on the variable of Implementation of Report Online Application. 
Variable of User Satisfaction

\begin{tabular}{|c|c|c|c|c|}
\hline & & & $P$ & Estimate \\
\hline Information quality & $<--$ & User satisfaction & & .989 \\
\hline System quality & $<--$ & User satisfaction & & .941 \\
\hline Service quality & $<--$ & User satisfaction & & .822 \\
\hline IQ4 & $<--$ & Information quality & & .654 \\
\hline IQ3 & $<--$ & Information quality & $* * *$ & .744 \\
\hline IQ2 & $<--$ & Information quality & $* * *$ & .920 \\
\hline IQ1 & $<--$ & Information quality & $* * *$ & .809 \\
\hline SQ4 & $<--$ & System quality & & .785 \\
\hline SQ3 & $<--$ & System quality & $* * *$ & .896 \\
\hline SQ2 & $<--$ & System quality & $* * *$ & .930 \\
\hline SQ1 & $<-$ & System quality & $* * *$ & .839 \\
\hline SQ5 & $<--$ & System quality & $* * *$ & .820 \\
\hline QS2 & $<--$ & Service quality & & .580 \\
\hline QS3 & $\begin{array}{l}<- \\
\end{array}$ & Service quality & $* * *$ & .800 \\
\hline QS4 & $<--$ & Service quality & $* * *$ & .878 \\
\hline QS5 & $<--$ & Service quality & $* * *$ & .884 \\
\hline QS1 & $<--$ & Service quality & $* * *$ & .763 \\
\hline
\end{tabular}

Table 6:- Regression Weights and Standardized Weights of User Satisfaction Variable

The standardized value estimate indicator of information quality is (0.989), system quality (0.941), service quality $(0.822)$ is more than 0.5 . With this, all indicators and dimensions are declared valid. Standardized estimates of indicators IQ1 (0,809), IQ2 $(0,920)$, IQ3 $(0,744)$, IQ4 $(0,654)$ to the dimensions of Information quality (information quality), indicators SQ1 $(0,839)$, SQ2 $(0,930)$, SQ3 $(0,896)$, SQ4 $(0,654)$ to the dimensions of Information quality (information quality), indicators SQ1 (0.839), SQ2 (0.930), SQ3 (0.896), SQ4 ( 0.785), SQ5 $(0.820)$ on the System Quality dimension, indicators QS1 (0.763), QS2 (0.580), QS3 (0,800), QS4 (0,878), QS5 (0.820) on the Service Quality dimension. Dimensions of Information Quality (information quality) of (0.989), System Quality (system quality) of (0.941), Service Quality (service quality) of $(0.822)$ on the variable User Satisfaction (user satisfaction).

\section{Construction Reliability Test}

Variable of Operational Performance

\begin{tabular}{|c|c|c|c|c|}
\hline & & & P & Estimate \\
\hline OP1 & $<--$ & operational_performance & & .989 \\
\hline OP2 & $<--$ & operational_performance & $* * *$ & .941 \\
\hline OP3 & $<--$ & operational_performance & $* * *$ & .822 \\
\hline OP4 & $<--$ & operational_performance & $* * *$ & .654 \\
\hline
\end{tabular}

Table 7:- Regression Weights and Standardized Weights of Operational Performance Variable

Standardized estimate values are OP1 (0.892), OP2 (0.883), OP3 (0.937), OP4 $(0,838)$ to Dimensions of Operational Performance.

\begin{tabular}{|c|c|c|c|c|c|}
\hline \multirow{2}{*}{ No } & & \multirow{2}{*}{ Konstruk } & CR & VE & \multirow{2}{*}{ Ket } \\
\hline & & & $\mathrm{CR} \geq 0.7$ & $\mathrm{VE} \geq 0.5$ & \\
\hline \multirow{8}{*}{1} & \multirow{8}{*}{ 1st CFA } & Perceived Usefullness & 0.814 & 0.673 & Reliabel \\
\hline & & PU1 & & & Valid \\
\hline & & PU2 & & & Valid \\
\hline & & PU3 & & & Valid \\
\hline & & PU4 & & & Valid \\
\hline & & $\Sigma$ & & & \\
\hline & & Perceived Ease of Use & 0.876 & 0.767 & Reliabel \\
\hline & & PE1 & & & Valid \\
\hline
\end{tabular}


ISSN No:-2456-2165

\begin{tabular}{|c|c|c|c|c|c|}
\hline & & PE2 & & & Valid \\
\hline & & PE3 & & & Valid \\
\hline & & PE4 & & & Valid \\
\hline & & PE5 & & & Valid \\
\hline & & PE6 & & & Valid \\
\hline & & $\Sigma$ & & & \\
\hline & & Implementation of Report Online & & & \\
\hline & & & 0.902 & 0.814 & Reliabel \\
\hline & 2nd CFA & Perceived Usefullness & & & Valid \\
\hline & & Perceived Ease_of_Use & & & Valid \\
\hline & & $\Sigma$ & & & \\
\hline & & Informatin Quality & 0.782 & 0.621 & Reliabel \\
\hline & & IQ1 & & & Valid \\
\hline & & IQ2 & & & Valid \\
\hline & & IQ3 & & & Valid \\
\hline & & IQ4 & & & Valid \\
\hline & & $\Sigma$ & & & \\
\hline & & System Quality & 0.854 & 0.732 & Reliabel \\
\hline & & SQ1 & & & Valid \\
\hline & & SQ2 & & & Valid \\
\hline & $1 \mathrm{st} C \mathrm{CF}$ & SQ3 & & & Valid \\
\hline & Ist CFA & SQ4 & & & Valid \\
\hline & & SQ5 & & & Valid \\
\hline & & $\Sigma$ & & & \\
\hline & & Service Quality & 0.781 & 0.622 & Reliabel \\
\hline & & QS1 & & & Valid \\
\hline & & QS2 & & & Valid \\
\hline & & QS3 & & & Valid \\
\hline & & QS4 & & & Valid \\
\hline & & QS5 & & & Valid \\
\hline & & $\Sigma$ & & & \\
\hline & & User Satisfaction & 0.917 & 0.846 & Reliabel \\
\hline & & Informatin Quality & & & Valid \\
\hline & 2nd CFA & System Quality & & & Valid \\
\hline & & Service Quality & & & Valid \\
\hline & & $\Sigma$ & & & \\
\hline & & Operational Performance & 0.888 & 0.789 & Reliabel \\
\hline & & OP1 & & & Valid \\
\hline 3 & $1 \mathrm{st} C \mathrm{CE}$ & $\mathrm{OP} 2$ & & & Valid \\
\hline 3 & Ist CFA & OP3 & & & Valid \\
\hline & & OP4 & & & Valid \\
\hline & & $\Sigma$ & & & \\
\hline
\end{tabular}

Table 8:- Reliability Construct Test Result 
ISSN No:-2456-2165

All dimensions and indicators of the research construct have a factor of trialability test results of constructs of more than 0.7 and variance extracts of more than 0.5 so that all indicators and dimensions in this study are valid and reliable (Joreskog and Sorborn; 1993). 1st CFA Value (CR \& VE) (perceived ease of use) (0.876 \& 0.767), 2nd CFA variable Implementation of Online Report Application (implementation of report online) $(0.902 \& 0.814)$, 1st CFA value for the Information Quality dimension $(0.782 \&$ 0.621), 1st CFA value for System Quality (0.854 \& 0.732), 1st CFA value for Service (Service Quality) (0.781 \& 0.622), 2nd CFA value for User Satisfaction variable $(0.917 \& 0.846)$, 1st CFA variable Operational Performance $(0.888 \& 0.789)$.

D. Test for Assumption of Normality and Outlier

\begin{tabular}{|c|c|c|c|c|c|c|}
\hline Variable & $\min$ & $\max$ & skew & c.r. & kurtosis & c.r. \\
\hline OP4 & 4.000 & 10.000 & -.556 & -2.712 & .901 & 2.199 \\
\hline OP3 & 4.000 & 10.000 & -.638 & -3.114 & .766 & 1.869 \\
\hline OP2 & 5.000 & 10.000 & -.759 & -3.704 & .818 & 1.996 \\
\hline OP1 & 3.000 & 10.000 & -1.031 & -5.032 & 2.352 & 5.740 \\
\hline QS1 & 4.000 & 10.000 & -.659 & -3.216 & .711 & 1.736 \\
\hline QS5 & 1.000 & 10.000 & -1.427 & -6.969 & 4.129 & 10.079 \\
\hline QS4 & 2.000 & 10.000 & -1.266 & -6.182 & 2.959 & 7.222 \\
\hline QS3 & 1.000 & 10.000 & -1.494 & -7.295 & 4.341 & 10.596 \\
\hline QS2 & 1.000 & 10.000 & -.974 & -4.755 & 1.556 & 3.798 \\
\hline SQ5 & 4.000 & 10.000 & -.743 & -3.627 & .866 & 2.113 \\
\hline SQ1 & 4.000 & 10.000 & -.564 & -2.753 & .774 & 1.889 \\
\hline SQ2 & 5.000 & 10.000 & -.665 & -3.247 & .382 & .933 \\
\hline SQ3 & 5.000 & 10.000 & -.542 & -2.648 & .008 & .019 \\
\hline SQ4 & 4.000 & 10.000 & -.966 & -4.718 & 1.358 & 3.315 \\
\hline IQ1 & 3.000 & 10.000 & -1.046 & -5.106 & 2.243 & 5.476 \\
\hline IQ2 & 5.000 & 10.000 & -.512 & -2.499 & .275 & .671 \\
\hline IQ3 & 3.000 & 10.000 & -1.114 & -5.440 & 2.069 & 5.051 \\
\hline IQ4 & 3.000 & 10.000 & -1.091 & -5.325 & 2.030 & 4.954 \\
\hline PE1 & 4.000 & 10.000 & -.735 & -3.587 & .837 & 2.042 \\
\hline PE2 & 5.000 & 10.000 & -.550 & -2.685 & .155 & .377 \\
\hline PE3 & 4.000 & 10.000 & -.480 & -2.345 & .721 & 1.759 \\
\hline PE4 & 3.000 & 10.000 & -.693 & -3.382 & 1.111 & 2.711 \\
\hline PE5 & 4.000 & 10.000 & -.647 & -3.160 & .373 & .910 \\
\hline PE6 & 5.000 & 10.000 & -.191 & -.933 & -.366 & -.892 \\
\hline PU1 & 3.000 & 10.000 & -.965 & -4.713 & 1.498 & 3.658 \\
\hline PU2 & 3.000 & 10.000 & -1.239 & -6.049 & 2.564 & 6.259 \\
\hline PU3 & 2.000 & 10.000 & -.821 & -4.010 & .480 & 1.173 \\
\hline PU4 & 4.000 & 10.000 & -.696 & -3.400 & .652 & 1.592 \\
\hline Multivariate & & & & & 417.330 & 60.878 \\
\hline
\end{tabular}

Table 9:- Normality Test Result 


\section{E. Goodness of Fit Test}

The overall goodness of fit test results are shown in the following table:

\begin{tabular}{|c|c|c|c|}
\hline $\begin{array}{c}\text { Goodness of } \\
\text { Fit }\end{array}$ & $\begin{array}{c}\text { Required } \\
\text { acceptance } \\
\text { limit } *\end{array}$ & $\begin{array}{c}\text { Results after } \\
\text { modification }\end{array}$ & Decision \\
\hline CMIN / DF & $\leq 2.00$ & 1,554 & Good fit \\
\hline NFI & $\geq 0.90$ & 0901 & Good fit \\
\hline IFI & $\geq 0.90$ & 0.962 & Good fit \\
\hline TLI & $\geq 0.90$ & 0.955 & Good fit \\
\hline CFI & $\geq 0.90$ & 0.962 & Good fit \\
\hline RMSEA & $\leq 0.08$ & 0.067 & Good fit \\
\hline PRATIO & $0-1$ & 0.921 & Good fit \\
\hline PGFI & $0-1$ & 0826 & Good fit \\
\hline
\end{tabular}

Table 10:- Goodness of Fit Test Results
Overall Goodness of Fit can be assessed based on a minimum of 5 (five) criteria that are met (Ghozali, 2017). According to Latan, 2012 citing Hair et al, 2010 said that the use of 4-5 GOF criteria was considered sufficient to assess the feasibility of a model, with the conditions that each criterion from GOF namely Absolut Fit Indices, Incremental Fit Indices and Parsimony Fit Indices represented (Haryono, 2017: 243). With the goodness of fit test results obtained the whole model can be considered feasible.

\section{F. Hypothesis test}

The final results of the modification of the model after testing the hypothesis obtained the following results:

\begin{tabular}{|c|c|c|c|c|c|c|}
\hline \multicolumn{2}{|c|}{ Parameter } & Estimate & Lower & Upper & P \\
\hline User_Satisfaction & $\leftarrow$ & $\begin{array}{c}\text { Implementation_of_Report_ } \\
\text { Online }\end{array}$ & 1.012 & .991 & 1.033 & .019 \\
\hline Operational_Performance & $\leftarrow$ & User_Satisfaction & .001 & .001 & .001 & .004 \\
\hline Operational_Performance & $\leftarrow$ & $\begin{array}{c}\text { Implementation_of_Report_ } \\
\text { Online }\end{array}$ & .933 & .872 & .958 \\
.018
\end{tabular}

Table 11:- Hypothesis Test Results

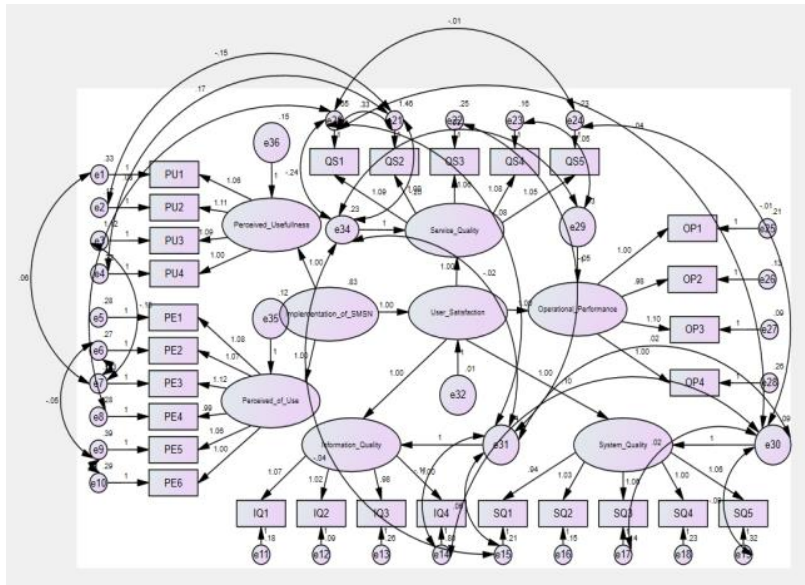

Fig 2:- Hypothesis Test Results

Based on the proposed research hypothesis which includes:

$>\mathrm{H} 1$ : Implementation of the Report Online Application has a positive effect on User Satisfaction

The results prove that in the $\mathrm{H} 1$ hypothesis, the implementation of report online application has a positive effect on user satisfaction with a significance level of $0.019, \beta=1.012$. Every increase of one unit of Report Online implementation will increase the level of user satisfaction by 1,012 .

H2: User Satisfaction has a positive effect on Operational Performance

The results of the study prove that in the $\mathrm{H} 2$ hypothesis, user satisfaction has a positive effect on operational performance with a significance level of 0.004 , $\beta=0.001$. Every increase of one unit of user satisfaction will increase operational performance by 0.004 .

H3: Implementation of the Report Online Application has a positive effect on Operational Performance

The results of the study prove that the hypothesis H3, the implementation of Report Online applications has a positive effect on operational performance with a significance level of $0.018, \beta=0.933$. Every increase of one unit of the implementation Report Online application will increase operational performance by 0.933 .

The results of the calculation of the indirect effect of applying the Report Online application to operational performance through user satisfaction amounted to 0.001 (1.012 X 0.001). While the total direct effect of the application of Report Online applications on user satisfaction amounted to 0.933 . Every increase in one unit of Report Online application implementation can improve operational performance through user satisfaction by 0.001 while the direct effect on operational performance by 0.933. This means that even without user satisfaction, Report Online application implementation can improve operational performance directly more significantly.

The results of this study also illustrate the relationship between indicators with dimensions and dimensions and variables of the Report Online implementation shown in table 12 below: 
ISSN No:-2456-2165

\begin{tabular}{|c|c|c|c|c|c|c|}
\hline \multicolumn{2}{|c|}{ Parameter } & Estimate & Lower & Upper & P. \\
\hline $\begin{array}{c}\text { Perceived } \\
\text { Usefullness }\end{array}$ & $\leftarrow$ & $\begin{array}{c}\text { Implementation of Report } \\
\text { Online }\end{array}$ & .912 & .860 & .949 & .015 \\
\hline Perceived of_Use & $\leftarrow$ & $\begin{array}{c}\text { Implementation of Report } \\
\text { Online }\end{array}$ & .930 & .894 & .963 & .005 \\
\hline PU4 & $\leftarrow$ & Perceived Usefullness & .855 & .797 & .913 & .003 \\
\hline PU3 & $\leftarrow$ & Perceived Usefullness & 707 & 603 & .788 & .012 \\
\hline PU2 & $\leftarrow$ & Perceived Usefullness & .932 & .896 & .960 & .007 \\
\hline PU1 & $\leftarrow$ & Perceived Usefullness & .871 & .818 & .917 & .005 \\
\hline PE6 & $\leftarrow$ & Perceived of_Use & .884 & .816 & .931 & .018 \\
\hline PE5 & $\leftarrow$ & Perceived of_Use & .865 & .796 & .924 & .009 \\
\hline PE4 & $\leftarrow$ & Perceived of_Use & .878 & .820 & .926 & .008 \\
\hline PE3 & $\leftarrow$ & Perceived of_Use & .947 & .917 & .966 & .014 \\
\hline PE2 & $\leftarrow$ & Perceived of_Use & .896 & .846 & .926 & .018 \\
\hline PE1 & $\leftarrow$ & Perceived of_Use & .896 & .860 & .929 & .010 \\
\hline
\end{tabular}

Table 12:- Test Results for Indicators and Variable Dimensions for PU, PE Report Online Implementation

The strongest influence on the variable implementation of report online application is shown by the dimension of Ease (perceived of use) with a loading value of 0.930 so that the ease factor in application operations most significantly determines the level of user satisfaction. While the perceived usefulness dimension has a loading value of 0.912 , thus the higher the value of the implementation of application benefits, the satisfaction felt by users is also increasing.

The results of the study of the relationship between indicators with dimensions and dimensions and user satisfaction variables are shown in table 13 below:

\begin{tabular}{|c|c|c|c|c|c|c|}
\hline \multicolumn{3}{|c|}{ Parameter } & Estimate & Lower & Upper & P. \\
\hline Information Quality & $\leftarrow$ & User Satisfaction & .913 & 859 & 966 & .006 \\
\hline System Quality & $\leftarrow$ & User Satisfaction & .939 & .884 & .972 & .009 \\
\hline Service Quality & $\leftarrow$ & User Satisfaction & .888 & .806 & .925 & .023 \\
\hline IQ4 & $\leftarrow$ & Information Quality & .775 & .675 & .884 & .008 \\
\hline IQ3 & $\leftarrow$ & Information Quality & .885 & .843 & .927 & .012 \\
\hline IQ2 & $\leftarrow$ & Information Quality & .958 & .935 & .981 & .005 \\
\hline IQ1 & $\leftarrow$ & Information Quality & .929 & .898 & .954 & .011 \\
\hline SQ4 & $\leftarrow$ & System Quality & .888 & .832 & .936 & .008 \\
\hline SQ3 & $\leftarrow$ & System Quality & .922 & .876 & .952 & .026 \\
\hline SQ2 & $\leftarrow$ & System Quality & .932 & .896 & 955 & .011 \\
\hline SQ1 & $\leftarrow$ & System Quality & .888 & .844 & .924 & .010 \\
\hline SQ5 & $\leftarrow$ & System Quality & .942 & .910 & .987 & .005 \\
\hline QS2 & $\leftarrow$ & Service Quality & .734 & .645 & .907 & .002 \\
\hline QS3 & $\leftarrow$ & Service Quality & .910 & .849 & .939 & .026 \\
\hline QS4 & $\leftarrow$ & Service Quality & .942 & .900 & .976 & .006 \\
\hline QS5 & $\leftarrow$ & Service Quality & .917 & .868 & .957 & .012 \\
\hline QS1 & $\leftarrow$ & Service Quality & .949 & .871 & 1.020 & .006 \\
\hline
\end{tabular}

Table 13:- Test Results of Indicators and Variable Dimensions of User Satisfaction IQ, SQ, QS 

below:

The results of the study of the relationship between indicators with operational performance variables are shown in table 14

\begin{tabular}{|c|c|c|c|c|c|c|}
\hline \multicolumn{2}{|c|}{ Parameter } & Estimate & Lower & Upper & P. \\
\hline OP1 & $\leftarrow$ & Operational Performance & .912 & .868 & .945 & .009 \\
\hline OP2 & $\leftarrow$ & Operational Performance & .936 & .894 & .965 & .014 \\
\hline OP3 & $\leftarrow$ & Operational Performance & .965 & .936 & 982 & .014 \\
\hline OP4 & $\leftarrow$ & Operational Performance & .891 & .812 & .922 & .028 \\
\hline
\end{tabular}

Table 14:- Test Results for OP Operational Performance Variable Indicators

The strongest influence of operational performance variable indicators is shown by the OP3 reporting accuracy output (0.965) so that the increasing use of reporting accuracy applications will increase significantly, OP2 reporting speed (0.936) with increasing application usage will further increase the reporting speed, reporting produced OP1 (0.912) an increase in application usage will further increase reporting results and the OP4 reporting error rate (0.891) with increasing application usage will further improve resolution of reporting errors.

\section{CONCLUSIONS AND SUGESTIONS}

\section{A. Conclusion}

Based on the analysis results, this study can be concluded as follows:

$>$ Implementation of the Report Online Application has a positive effect on User Satisfaction. The greater utilization of Report Online applications will increase the level of user satisfaction.

$>$ User Satisfaction has a positive effect on Operational Performance. Increasing user satisfaction will increase operational

> Implementation of the Report Online Application has a positive effect on Operational Performance. By increasing the utilization of Report Online application, it will further improve operational performance.

$>$ Implementation report online application can improve operational performance directly more significantly, so user satisfaction is not a mediation variable

\section{B. Suggestion}

$>$ The strongest influence of variables. Implementation of online report applications is shown in the dimension of ease so that to increase the level of reliability and acceptance of the application, it is necessary to facilitate the rational use of the application.

> System quality has the strongest influence on user satisfaction so that a good quality system is needed to increase the level of user satisfaction. In general, the use of information systems using applications with online report application case studies increases user satisfaction and improves operational performance so as to help organizations achieve goals.

$>$ Accuracy of reporting has the most significant effect in determining operational performance, so the use of applications must be able to improve reporting accuracy so that it will improve operational performance
It is necessary to do further research by testing different applications as a comparison and reinforcing conclusions

\section{REFERENCES}

[1]. Arif Surachman. (2007). Analysis of Acceptance of Version 3 Integrated Library Information System (Sipus) in Gadjah Mada University (UGM). Yogyakarta.

[2]. Bahri, S., \& Si, M. (2017). Analysis of Factors Affecting (Case Study at PT. Perkebunan Nusantara 1 Cot Girek). Aceh

[3]. Dan, P., Kerja, D., Study, P., Faculty, M., University, E., \& Surabaya, B. (nd). BPS Employee Productivity in East Java Province. Surabaya

[4]. Huang, KE, Wu, JH, Lu, SY, \& Lin, YC (2016). Innovation and technology creation effects on organizational performance. Journal of Business Research.

[5]. Kobelsky, K., Larosiliere, G., \& Plummer, E. (2014). The impact of information technology on performance in the not-for-profit sector. International Journal of Accounting Information Systems, 15 (1), 47-65. https://doi.org/10.1016/j.accinf.2013.02.002

[6]. Maulana, Dede and Sulistyowati, Niken (2020). The Influences of Occupational Safety and Health, NonPhysical Work Environment on Employee's Productivity at PT XYZ. International Journal of Innovative Science and Research Technology (IJISRT) Volume 5, Issue 1, January - 2020.

[7]. Lipaj, D. (2013). Influence Of Information Systems On Business Performance. 5 (1), 38-45. https://doi.org/10.3846/mla.2013.06

[8]. Nurmaini, D., \& Ger, M. (2016). Analysis of customer acceptance of the PLN Website Information System with the TAM model. National Seminar on Indonesian Information Systems, (November).

[9]. Putra, AR, Wijaksana, TI, Sos, S., \& Si, M. (2015). Utilization of Information Systems Against the Work Productivity of PT. Telekomunikasi Indonesia Witel East Jakarta (Study at https://portal.telkom.co.id) Use of Information Systems on the Productivity Network Unit of PT. Telecommunications In. 2 (3), 3726-3732.

[10]. Sensuse, DI, \& Prayoga, SH (2012). Usability Analysis in Web-Based Applications By Adopting a User Satisfaction Model. Journal of Information $\begin{array}{llll}\text { Systems, } & 6 & (1), & 70 .\end{array}$ https://doi.org/10.21609/jsi.v6i1.278. 
[11]. Sirisomboonsuk, P., Gu, VC, Cao, RQ, \& Burns, JR (2018). Relationships between project governance and information technology governance and their impact on project performance. International Journal of Project Management, $36 \quad$ (2), 287-300. https://doi.org/10.1016/j.ijproman.2017.10.003.

[12]. Wati, T., Seta, HB, \& Isnainiyah, IN (2017). Usability Measurement and E-Learning Evaluation for Training Programs for Education Personnel Usability Measurement and Evaluation of E-Learning to Support the Training Program for Academic Staff. 2 (2), 177-84

[13]. Widianingsih, R., \& Primasari, D. (2004). The Influence of the Implementation of the Regional Financial Information System on Employee Performance: Clarity of the Role as an Intervening Variable (Empirical Study on Regional Work Units of the Banyumas Regency). 414-424

[14]. Widodo, A., Putranti, HRD, \& Nurchayati. (2016). The Effect of Application System Quality and Information Quality on User Satisfaction of RTS (Rail Ticketing System) Application Systems. Jurmal Media Economics and Management, 31 (2), 160-181

[15]. Wijaya, Eri and Niken Sulistyowati, Niken (2019) The Effect of Application of Hospital Management Information Systems on Operational Performance Through User SatisfactionMaster European Journal of Business and Management Vol.11, No.36 - 2019 